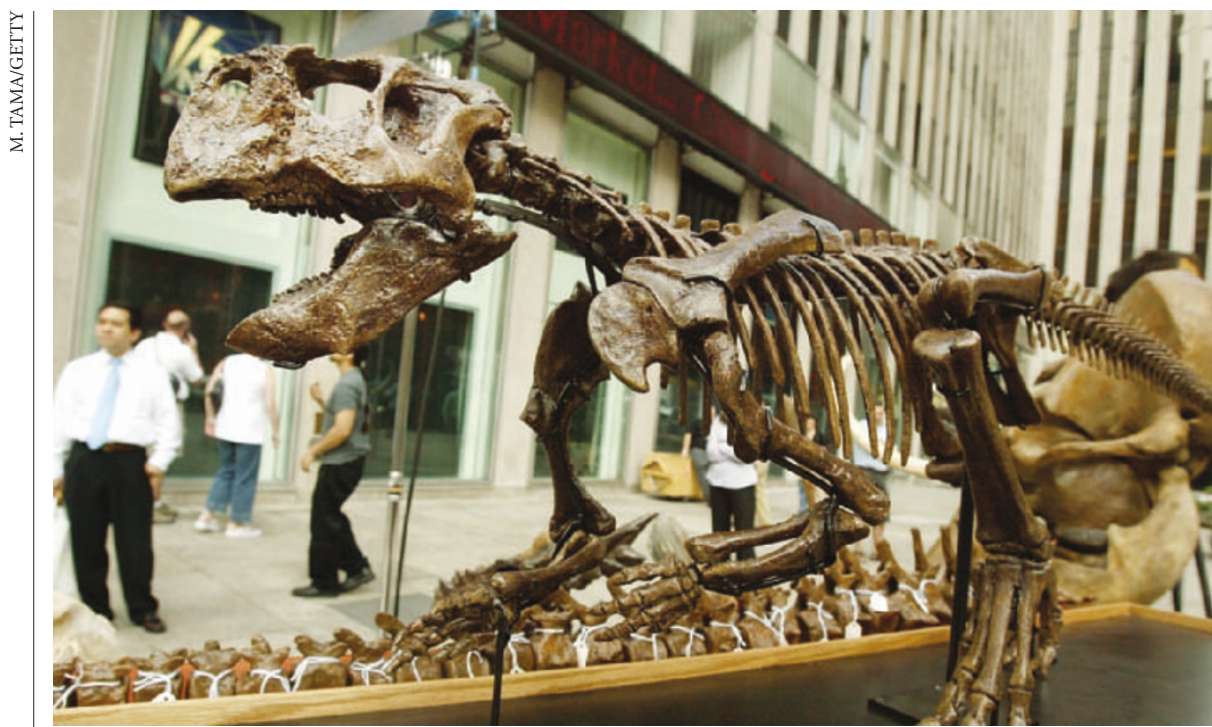

Bad eggs: a New York auction house decided not to put fossilized embryos under the hammer.

\section{Dinosaur eggs escape sale as smuggling claims unearthed}

Rex Dalton, San Diego

An outcry among palaeontologists — and a little help from US federal agents — has saved some dinosaur embryo fossils from disappearing into the living room of a wealthy patron. But questions remain as to how the half-dozen specimens, thought to have been smuggled out of Argentina, will be repatriated for study.

The fossils, which were set to be auctioned on 24 June at Guernsey's in New York City, include some valuable specimens, such as a dinosaur egg in which the skull of a sauropod embryo can be seen. "It is a tremendous specimen, extremely rare," says Luis Chiappe, an Argentinian palaeontologist who is a curator at the Natural History Museum of Los Angeles County. Such detailed fossils could be used to study the early development of dinosaurs.

When Argentinian government officials learned from US palaeontologists that the illicit dinosaur embryos were to be sold, they contacted the US government, which took the unusual step of directing the Federal Bureau of Investigation to contact Guernsey's auction house. The embryo fossils were then removed from the auction. They are now being held in New York, and efforts are under way to get them back to Argentina.

Palaeontologists have also raised questions about the background of other fossils that went unsold in the auction, which were listed as being from China but which scientists say were probably smuggled from Mongolia. These fossils are still owned by commercial fossil-dealer Zee Haag of Tucson, Arizona.
The Argentinian fossils were brought to the auction by Terry Manning of Leicester, UK, who has collected dinosaur eggs for about 15 years. He has refined an acid-etching technique to reveal embryonic material in fossils.

Manning says he bought the dinosaur eggshells two years ago at a fossil show in Tucson, Arizona. He says he took the shells to England to clean them up, and then brought them to New York, mentioning to US customs agents that the specimens were probably originally smuggled from Argentina. The agents told him to "Have a good auction," he says.

Although Manning says he would appreciate some money for his fossils, he adds: "The most important thing is that the research work must be completed on the specimens." This is only likely to happen if the fossils wind up in government hands, rather than in a private collection. The Argentinian government is keen to take them, although Marcelo Cema, a spokesman at the Embassy of the Argentine Republic in Washington, is adamant that it will not pay for transportation of the "stolen property".

If anyone wants to retrieve Haag's fossils to send them home to Asia, it will cost them. Haag says his three-metre-long Tyrannosaurus bataar skull, for example, is worth at least US\$160,000. Palaeontologist Mark Norell of the American Museum of Natural History, New York, says someone probably smuggled the skull out of Mongolia. Haag says he bought the skull and other specimens in Tokyo, and shipped them to Arizona, claiming them properly for import. As to whether these specimens would be better off in a lab than on the auction block, Haag simply says: "I'm an American capitalist." -
Swedish enthusiasm peps up plans for neutron source

Quirin Schiermeier, Munich

An ambitious plan for a powerful neutron facility in Europe has been reawakened by a show of interest from Sweden. There are as yet no promises that the facility will be built — let alone a decision on where - but Sweden's move has fuelled hope in the 5,000-strong European neutron community that the project will finally go ahead.

Europe announced plans in 1992 to build the European Spallation Source (ESS), a facility designed to be the most powerful neutron source in the world. The ESS would produce neutrons by accelerating protons at a heavy metal target - such neutrons can be used to probe materials from proteins to plastic and steel. Although other neutron sources are planned in the United States and Japan, the ESS would be more powerful and flexible than these.

By 2002 the technical plans were finalized, but in 2003 both Germany and Britain withdrew support, in a move that seemed to kill off the $€ 1.5$-billion (US\$1.8billion) project (see Nature 421, 563; 2003).

On 16 July, the Swedish government asked former minister of finance, Allan Larsson, to review the possibility of hosting the facility. Larsson has a oneyear mandate to garner support for the project - or a scaled-down version from European governments, science agencies and industry. If he succeeds, next summer Sweden will submit a formal bid.

"I am absolutely delighted," says Bob Cywinski, a physicist at the University of Leeds, UK, and a long-time lobbyist for a Yorkshire site for the ESS. "Of course I'd favour it being built in Britain, but Sweden's move will definitely dispel the notion that the ESS is a dead project." At the same time, an umbrella organization -the European Spallation Source Initiative - is being set up in Grenoble, France, to oversee the project.

There are other contenders for hosting the site, however. Hungary is expected to come up with a formal bid later this year. And Britain, which operates what is currently the world's most intense neutron source at the Rutherford Appleton Laboratory near Oxford, may also remain an option.

It would take about ten years to build the ESS, so advocates are pressing for a decision to be made on its location as soon as possible. "We could start building tomorrow," says Cywinski. 